\title{
Parmenides on the True and Right Names of Being
}

\author{
Mostafa Younesie \\ Independent scholar in Classical Greek Philosophy of Language \\ Philadelphia, UNITED STATES
}

Received: 14 February 2021 - Accepted: 12 April 2021 - Published Online: 15 April 2021

\begin{abstract}
Parmenides as a knowing mortal (F I. 3) writes a philosophical-poetic account of a travelogue in which distinctive voices (F. 2) that are a mixture of myth and logos come out of an unnamed goddess (F I. 23) who didactically speaks with an unnamed young man as her direct listener and addressee (F II. 1) in order to reveal for him different spheres and routes (F II. 2) of inquiry about a specific referent. In the hybrid and tailored account of the immortal about a specific subjectmatter, such as being, we can read different approaches of the thoughtful mortals through the narration of the goddess, and the idea of the immortal herself. And exactly when thoughtful mortals want to introduce their thinking and understanding of the "referent" in human lingual terms they appeal to the act of naming and making names, though there is no explicit account by the immortal about her approach for lingual expressing of the referent. Such an account gives us some useful and distinctive hints about Parmenides' conception as a mortal about naming/names which makes his conception in a specific position in regard to the other pertinent and close words,

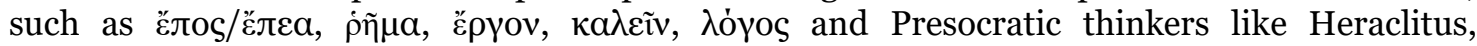
Democritus, and Empedocles. According to the immortal's account, in relation to naming and names thoughtful mortals can be classified mainly into two groups: (1) Those who are in Aletheia are informed of the distinctive features of the referent that is a "totality" and should be able to make "true" names for it but fail (F8. 38-39). If they succeeded, then their naming and names are true/ $\dot{\alpha} \lambda \eta \theta \tilde{\eta}$; and (2) those who are in Doxa think to know the features of the referent that is a "dual" and accordingly thoughtful mortals make names. Though all of names that are made are

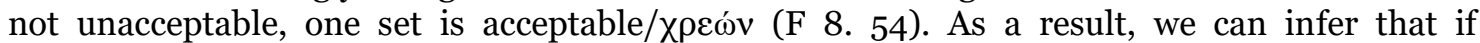
Parmenides as a thoughtful mortal wants to express his thought about eon in lingual terms, he should appeal to naming and making names for they have specific dynamis (F IX. 2-a term that appears in Plato's Cratylus 394b) in communicating the nature of any specific referent. The first best situation or Aletheia is where on the basis of his "knowledge", he can communicate the distinctive features of eon in names and thereby make "true" names. Besides, there is the second best or Doxa, where he can communicate his "beliefs" about the essence and essential features of eon in names and make "acceptable" names.
\end{abstract}

Keywords: Parmenides, poem, name, naming, true, right.

Within the framework of his philosophical poem, Parmenides writes a travelogue in which a kouros narrates the speech of a Goddess who addresses him. Before considering the topic of this paper, which is our account of the mortals' approach to and engagement with the subjectmatter of the goddess in the form of naming on two levels, we will pause initially to consider the texture and different manifestations of [sound and] voice that are produced by the immortals and mortals.

(C) Authors. Terms and conditions of Creative Commons Attribution 4.0 International (CC BY 4.0) apply. Correspondence: Mostafa Younesie, Independent scholar in Classical Greek Philosophy of Language. Philadelphia, UNITED STATES. E-mail: younesie 7@yahoo.com. 
In the first fragment and initial lines of Parmenides' Proem (I use Graham [2010], the First edition and translation with some corrections), we face with the specific utterance

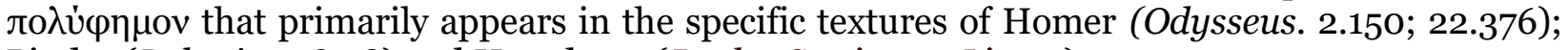
Pindar (Isthmians 8.58) and Herodotus (Book 5 Section 79 Line 4) too:

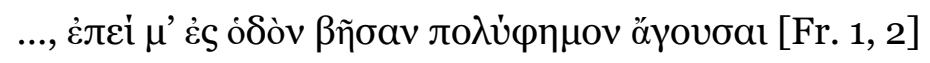

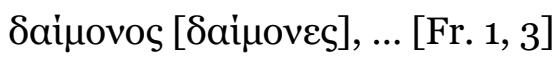

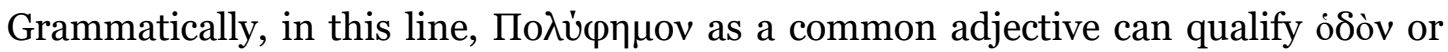

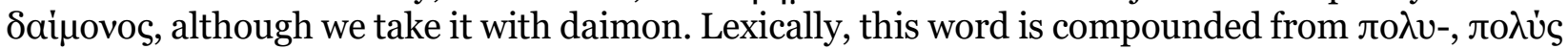
$+\varphi \dot{\eta} \mu \eta$ and the core of its meaning as a whole lie in the meaning of the noun $\varphi \dot{\eta} \mu \eta /$ speaking. The essence of the $\varphi \eta \dot{\mu}$ as a specific kind of speaking returns to its "origin" that is basically beyond human field and resides in the sphere of gods, goddesses, dreams, and the like. For this reason, it has specific meaning and importance for its receiver. In other words, such a speaking is basically oral and is prompted by god/goddess. It has a divine significance, apart from its meaning, that makes it somehow mysterious, private, and awesome for its recipient. At the same time, alongside this initial religious-laden connotation, $\varphi \eta \dot{\mu}$ has a general meaning that applies for any speaking that is not exclusively private and mysterious in its origin and for its receiver. And as a derived meaning, we have the term for an individual who is "much spoken about" and it means that he is "famous (Mourelatos, 2008: 41 n. 93; Semenzato, 2017: 294-295).

With regard to this background and the context of the second verse, if we consider the referent of $\varphi \eta \dot{\eta} \mu$ to be $\delta \alpha i \mu \omega v$, it means that $\delta \alpha i \mu \omega v$, as a divinity or supernatural being that is between gods and humans, can produce specific divinely inspired utterances.

In later lines of the same fragment, in the general texture of anonymity, we face with the second specific formation of utterance by identified entities. We can see this in relation to the previous passage too:

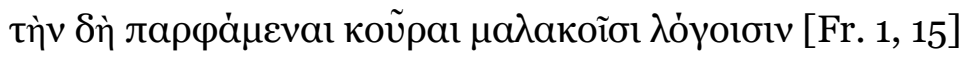

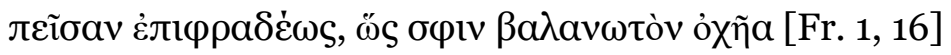

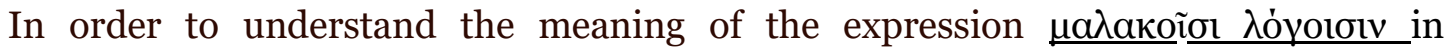
Parmenides' proem, we should consider some comparative textual and philological points. First of all, we can read the same combination with one more adjective in Odysseus too: aỉè $\delta \dot{\varepsilon}$

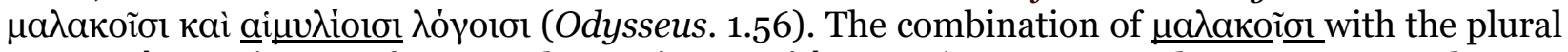

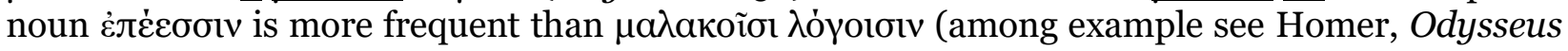
10.70; Hesiod, Theogony. 90; Homeric Hymn to Demeter. 336; and Orpheus, Argonautica, 1093). Accordingly, it seems a good idea to compare $\lambda$ óyos and हैं are translated with the same word, in order to see their distinctions and similarities. It seems that the essence of the ancient Greek word logos in the field of speech denotes to a set that choosing and putting together pertinent words of any subject-matter in order to say something is crucial. This core meaning can be detected in Parmenides' use of $\lambda$ óyos.

In comparison with $\lambda$ óyos, in the word हैंगоs, that will appear in the following verses from the narrator and the mouth of the Goddess herself, the conception of the speaker who utters words of a speech or song are prominent. As a result, the meaning of this word is dependent on the context in which it appears (Cunliffe, 1924: 152, 153).

After our philological minutiae, one factor that can help us for figuring out the sense

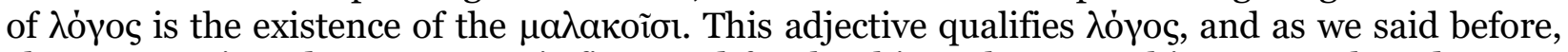
also appears in Odyssey 1.56. It is first used for the things that are subject to touch and means mostly soft things; then it is transformed for other entities too (such as individuals, ways of life, style, music, and reasoning) that literally are not subject to touch. With respect to its subject, it takes appropriate meaning that implies softness and gentleness in favorable or unfavorable and 
biased connotations (http://stephanus.tlg.uci.edu/lsj/\#context=lsj\&eid=109207: 1843 ). Therefore, when $\mu a \lambda a \kappa o ́ s$ qualifies $\lambda$ óyos, it can mean speeches that are not hard and harsh but gentle, soft, and fair. But such a conclusion not sufficient, for according to the place and state of $\lambda$ óyos, there are three other words that add their special flavor and color to it. We begin with the

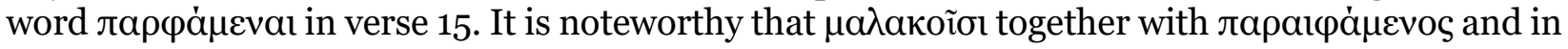
relation to the words of speech appear, for example, in Homeric Hymnto Demeter. 336; Hesiod, Theogony. 90; and Orpheus, Argonautica 1093. We also encounter the second combination withregard to our former philological points about this word, here too we are faced with a specific utterance about which we know only the result, and not the content. We know that the utterance of the кoũ $\rho a$ impresses its hearer and induces her to do a specific action: opening the gates. The combination of $\pi \alpha \rho \dot{\alpha}-$ with $-\varphi \eta \mu \mathrm{u}$ in metaphorical sense give to this verb a crucial twist in sincere or insincere (both meanings have evidences in: Pindar, Nemean 5.32; Olympian 7.66; Pythian 9.43: Hesiod, Theogony. b9o; Homer, Iliad. 12.249, and Odyssey. 2.189), and, as a result, the whole compound denotes to an utterance that wants to induce an action from a specific hearer by making a change and turning in the mind of his or her hearer-we can consider it is a kind of speech-act (http://stephanus.tlg.uci.edu/lsj/\#context=lsj\&eid=109207: 1843).

With regard to this conception, when we refer to the verse 15, we can say that koũpar by their speaking and through soft and gentle arrangement of their utterances wants to make a change in the mind of Dike in order that she will perform a specific action. And it is natural that this brief persuasion demands that they have rhetorical and deliberative convincing skills that they have and apply them successfully (Mourelatos, 2008: 146, 147).

Thereby, we reach to the warm and friendly reception of the narrator by goddess and her address to him, presented in direct quotation. However, the goddess's speech is not homogenous and as a result before starting her two-level speech, she informs and even warns her listener about the specific quality of her utterances. But before we consider these two specific levels, it would be better to have a general picture of the quality of her speech. When we consider her speech, we are faced with a set of words, such as $\dot{\varepsilon} \rho \dot{\varepsilon} \omega, \mu \tilde{v} \theta 0 v, \varphi \rho \dot{\zeta} \zeta \omega, \pi 0 \lambda \dot{v} \delta \eta \rho ı v ~ \varepsilon ँ \lambda \varepsilon \gamma \chi 0 v$,

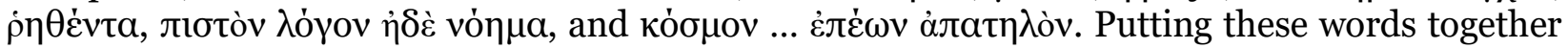
as a cluster shapes an overall image of her account. I want to consider these words and their specific identity in order to reach to their appropriate equivalents and at the same time form an organic image of goddess's speech, for it is exactly here that the necessity of human naming and names and their power and standard of being true and right becomes the concern of this paper.

\section{Features of Goddess' Speech}

Before beginning our examination of the words mentioned above, it is necessary to say that goddess is speaking to a human being who has specific qualities. This is one of the criteria that she observes in presenting her speech to him. On the one hand, indirectly the narrator introduces himself as a "عißóta $\varphi \tilde{\omega} \tau \alpha$ ", and on the other hand, the goddess addresses him as a "кoũ $о$ " " and we know there are different translations of and interpretations about this word (for a concise literature review, see Cosgrove, 1974: 81-94). Now with regard to the core of these words and their textures in the proem and the poem as the whole, let us try to find some equivalents. If we take the derivation of the noun кoũ $\rho \circ$ from the verb kei $\rho \omega$, we should consider three interconnected features of the verb: There is a supposed specific purpose for an unformed thing with specific qualities that can be transformed or worked upon and; which id brought of its indeterminate state; and becomes ready for its new function and role. In connection with the triad

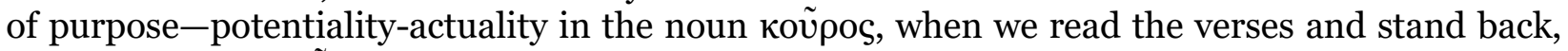

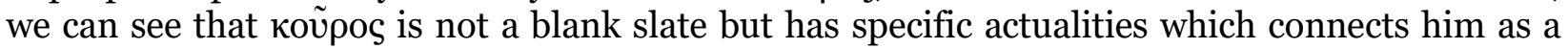
human being with the other men; but he is more than common people for he can go beyond them 


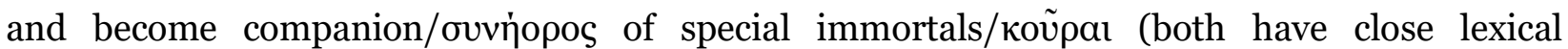
homonymy though different in the essential nature [Fr. 1, 24]). By their guidance, he becomes the only and sole addressee of an unnamed goddess. Then, the goddess forms her direct and unmediated utterances in a form that is suitable for an addressee with specific capabilities, possessions, and purpose and she can guide him in order to develop and reach to his goal. This point demands to see the narrator's understanding of himself besides the conception of goddess.

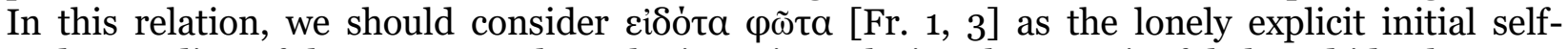
understanding of the narrator. Then, the issue is exploring the meaningful shared idea between

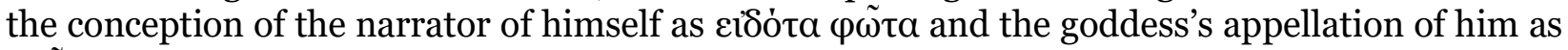
коüpos. For according to the texture of the proem verses and the word philology, it seems that goddess wants to speak with to a young boy who seems unsatisfied with what has reached and has "passion" to journey the unexplored "paths". At the same time, our narrator conception of himself

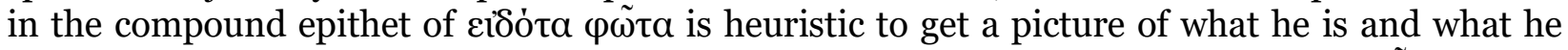
aspires and expected to acquire through his journey. The singular masculine noun $\varphi \tilde{\omega} \tau \alpha$, which appears only once in Parmenides' poem, has a great frequency in earlier and contemporaneous ancient Greek writers. For example, if we consider it in comparison with $\dot{\alpha} v \dot{\eta} \rho$, this word denotes to a kind of vagueness, so that its suitable English equivalent is "somebody" who is alive. Here in the third verse, due to the gender of the noun-adjective pair, we say that this anybody is a "man" in contrast with any "immortal", "animal", and "woman" (compare with Frere, 2017: 136). But philosophically, such a specification is not enough and we should go further. Interestingly, according to the structure of the sentence, we see that $\varphi \tilde{\omega} \tau \alpha$ participates and is involved in cißóta and not only this word plays a crucial role in Parmenides conception of himself; but also points to the necessity of initiating his serious and purposive imaginative journey. Thus, ciónta works as a necessary springboard that bring "somebody" out of his in distinction and make him distinctive and concrete by putting him in another stage and grade-journey as a transformative process.

In the related literature, there are many diverse and even opposite understandings of the four appearances of عiठóta in Parmenides' poem. By considering the other three occurrences of this word, we can reach an understanding of its meaning in relation to $\varphi \tilde{\omega} \tau \alpha$. Initially, whether we connect it with the knowledge by reflection and understanding (Coxon, 2009: 272), and knowledge derived from observation (Cosgrove, 2011: 31, 32), or knowledge by inspiration, according to the context of proem and common sense, it should be a specific kind of knowledge. The specificity of the knowledge is necessary because if the $\varphi \tilde{\omega} \tau \alpha$ has no knowledge, he will have no interest in and motivation for journey. If, on the other hand, the $\varphi \tilde{\omega} \tau \alpha$ considers himself perfectly wise and knowledgeable he has no need for a journey; and if he speculates on a journey, it will not be serious but something for amusement and play. Therefore, he has some kind of knowledge that is necessary but not sufficient and he need to make a journey to acquire sufficient knowledge. This means that Parmenides as the poet-philosopher knows that he does not know something that he should know. And it is exactly here that our understanding of the goddess' speech plays a vital role for the nature of what he knows and what he does not. The importance of speech will become clear when we consider the nature of the goddess' utterance and her instruction that he should "hear"-this action is emphasized in many places without any mentioning "to see"-and "think" about it. To consider this issue, we should explore the words that goddess uses to describe what she is going to deliver to the young boy.

On the basis of the wording of goddess as it comes through the mouth of the youngboy narrator, we have extracted these basic words describing the nature of goddess' didactic speech and the haves and haves-not of her addressee too: $\dot{\varepsilon} \rho \dot{\varepsilon} \omega, \mu \tilde{v} \theta o v, \varphi \rho \dot{\zeta} \zeta \omega, \pi 0 \lambda \dot{v} \delta \eta \rho v v \varepsilon \dot{\lambda} \varepsilon \gamma \chi 0 v$,

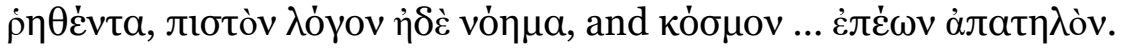

We begin with the word $\varphi \rho \dot{\jmath} \zeta \omega$ which is simpler that in comparison with the other words of this group. In the two occurrences in the second fragment (Lines 6 and 8), this word has a simple (not complicated) and concrete (not abstract) meaning of "to show something by finger" 
before "to say or declare something" (Mourelatos, 1974: 261). The next simple word, $\dot{\eta} \theta \dot{\varepsilon} v \tau \alpha$ (Fr. 7,5 ), does not have an established and distinctive meaning according to lexicons. For understanding its meaning, we should consider it under other more customary and usable words,

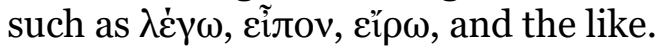

Therefore, we begin with the word $\dot{\varepsilon} \rho \dot{\varepsilon} \omega$ (Fr. 2, 1) with which the goddess says she wants to tell a tale. On the basis of Homeric corpus, the "verbal and relatively detailed account about anything" (Cunliffe, 1924: 114) comprises the core of this verb in distinction of the other Greek verbs related to facets of "saying". The same meaning is applicable to Parmenides poem, for we anticipate the goddess telling us a rather detailed verbal account about a specific topic which addressee can hear. Such an account of something cannot be in the form of few words or incomplete sentences, and one who wants to receive such a saying should listen to it, for $\dot{\varepsilon} \rho \dot{\varepsilon} \omega$ has

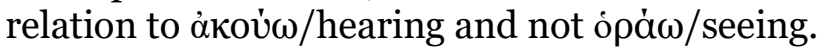

Therefore, we should expect that goddess tells a detailed tale (Fr. 2, 1). The goddess says that what she wants to present to the young-boy is a $\mu \tilde{v} \theta o s$, which should be told by her and heard by a hearer. With regard to the etymology of $\mu \tilde{v} \theta$ os as a type of speech (Barthes, 1993: 107), this means that she and her addressee are basically within the field of orality. It is natural that she delivers something verbally to an interested and apt hearer, who should listen thoughtfully. Therefore, the core of goddess' $\mu \tilde{v} \theta o s$ in Parmenides (although the word is also as problematic in relation to human beings) is the oral deliverance of anything by a speaker that is received by a hearer.

According to this background, after the goddess brings her account under the title of $\mu \tilde{v} \theta$ os, we expect her narration to follows as a specific kind of speech, as it does [in F2, 1; F 8, 1 ]. In other words, when we take Homer as stating-point, we can say that for understanding $\mu \tilde{v} \theta o \varsigma$, it is necessary to have a conception of its very general etymon, and then to bring out its contextual sense with regard to specific context in which it appears. It means that, when we read Homer, $\mu \tilde{v} \theta$ os has specific lexical meaning of saying and speaking, while in different contexts it acquires different colors (Morgan, 2000: 17; Cunliffe, 1924: 274).

But it seems that Parmenides use of $\mu \tilde{v} \theta$ os is different from poet's for here the young-

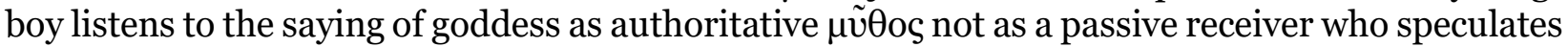
about the complete identity between what is said and the reality but as a possessor of $\lambda$ óyos who uses it in order to assess the $\mu \tilde{v} \theta$ os of the goddess. Nevertheless, $\mu \tilde{v} \theta$ os has no negative connotation for Aletheia for it is expressed through $\mu \tilde{v} \theta$ os, in other words, it is embedded within it. This issue again emphasizes the orality of the entire poem, which is only written afterwards.

Speaking of $\mu \tilde{v} \theta$ os leads us to consider $\lambda$ ójos. In addition to the previous sweet words of the Kouroi, the goddess also mentions $\lambda$ óyos in her $\mu \tilde{v} \theta$ os. From her position as goddess, she uses $\lambda$ óyos as a common thing between her and the young-boy $[\mathrm{F} \mathrm{7,5]}$ and then connects it with

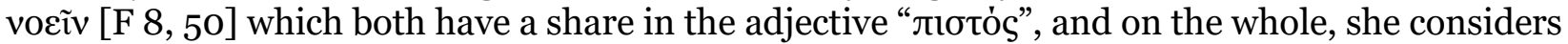
that her tale has this quality of trustworthiness. According to goddess' self-understanding, her oral

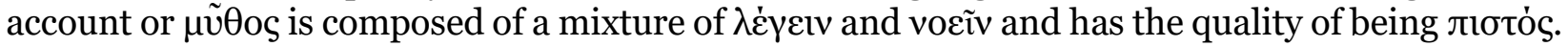
Thus, we should consider $\lambda \dot{\varepsilon} \gamma \varepsilon ı v$ in its connection with voeĩ (the oral context justifies the priority of the former over the latter) and then consider their common adjective to see what all these as a complexity mean on the level of Aletheia (Fr. 8, 50).

In other words, within the context of orality that poem is performed, $\mu \tilde{v} \theta o s$ is a kind

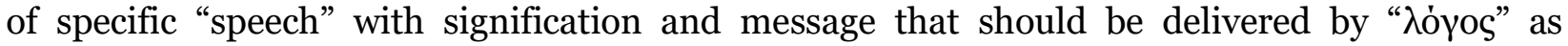
discourse. We will consider the different manifestations of this discourse in the goddess' account.

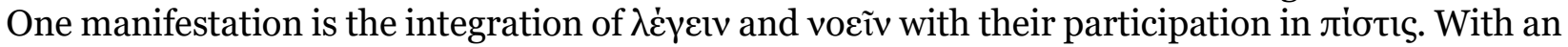
emphasis on orality and speaking, it is natural that $\lambda$ óyos have priority, but voeĩv comes after it as a compound of intuition and reasoning (von Fritz, 1974: 51, 52) in order to give specific color to 
$\lambda$ joyos. But there is not complete assurance yet and, as a result, goddess links both of them to riotis. It means that on the level of Aletheia the goddess's narration, which is a composition of her speaking and thinking (as a relatively appropriate equivalent for voeĩv), takes its specific identity

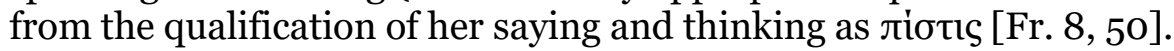

Here is one of the seven or eight places that we see a derivation of $\pi \varepsilon \imath \theta$ - in the form of an adjective. With a view to pre-Parmenides background, we can say that rious contains six components that interplay with each other and shape an organic whole. In analytical terms, this word is basically performative or perlocutionary (Mourelatos, 2008: $144 \mathrm{n}$. 27). It means that if we suppose two A and B parties, there is: (1) an initial promise, offer, proposal, or invitation by A to B; (2) B's endorsement or acceptance of that promise; (3) B's counter promise or pledge; (4) the continued maintenance of the relationship to the benefit of $\mathrm{B}$ and as the responsibility of A; (5) the continued maintenance of the relationship to the benefit of A and as a responsibility of B; and (6) the continued maintenance of the relationship as the responsibility of, and to the enjoyment of, both parties (Mourelatos, 2008: 139-140, 143). With regard to this account and genealogy of riotıs in the fields of theology and rhetoric, the equivalents of this adjective can be both "persuasive" and "faithful". It means that the goddess, in telling the tale or her oral performing, passes the young-boy through a mixture of religious initiation and reason, and as a result, demands the examination by her direct and unmediated addressee. This creates a mutual responsibility and benefit for both the goddess and young-boy (and the other readers of the poem too). It is a mutual equal movement from persuasion to faith and from faith to persuasion, which occur on the level of Aletheia as we read.

Another related phrase that the goddess uses on the Aletheia level is $\pi \circ \lambda \dot{v} \delta \eta \rho ı v$

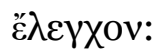

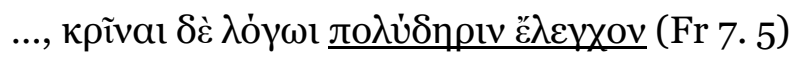

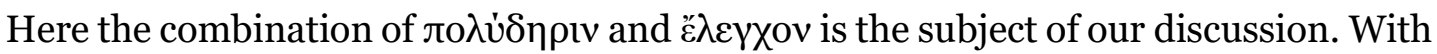
a view to the thumb-nail historical sketch of the well-known words $\dot{\varepsilon} \lambda \varepsilon \gamma \chi O \varsigma$ and $\dot{\varepsilon} \lambda \dot{\varepsilon} \gamma \chi \omega$ in Homer and Hesiod and especially Pindar and Bacchylides, we can say that the core of this word in prephilosophical meaning denotes to a kind of test and examination of things or humans in order to bring out their true nature. We examine $\varepsilon \grave{\lambda} \varepsilon \gamma x \circ \varsigma_{\text {in }}$ Parmenides' poem; it means orderly examination and testing of the available ways of thinking or options for enquiry (Lesher, 1984: 9, $16,17)$. And with regard to the word $\pi 0 \lambda \dot{v} . \delta \eta \rho ı$, we recognize that such a testing is full of strife and contention. This means not only that $\varepsilon^{\prime} \lambda \varepsilon \gamma \times O \varsigma$ is not something acceptable, commonsensical, consensual, and for-granted but also that it has many divisions, aspects, and dimensions (Ibid.:

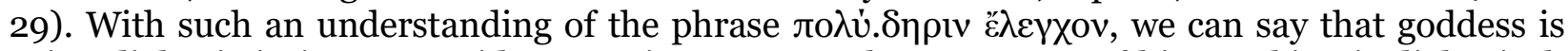
using dialectic in its Parmenidean version; as a result, one aspect of his speaking is dialectical. More concretely, I mean that the ways of thinking or options of inquiry and the quality of the fragments before (with the exception of the first fragment) and after (Fr 7.5) up to the level of Doxa-by using positive and negative and sometimes mixed combinations of them-forms a specific pattern and form that can be called dialectic (Austin, 2007: X, 3, 23).

By considering this quality of goddess expression, we come to another and final quality of her speaking to the young-boy. On the level of Doxa, we find characteristic that it is on the level of "seeming" things. As a result, the knowledge comes from thinking about such things is "uncertain and probable". It is analogous to the level of Aletheia that belongs to Being and certain knowledge and which, as we can noted, roots in riotıs. As a result of this characterization, we will expect the goddess to reflect and manifests the specific ontological/epistemological quality of Doxa level in his speaking and thinking, in parallel with the former sphere Aletheia:

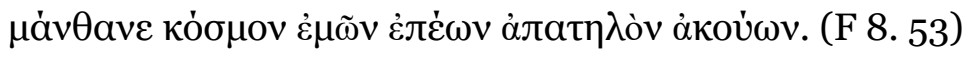

Here the goddess explicitly speaks of the quality and arrangement of her performative 


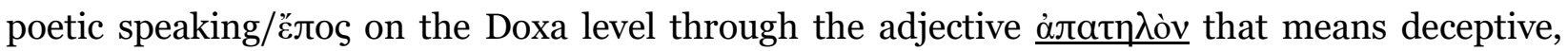
deceivable, illusionary, and tricky (LSJ 1843, 181). Moreover, the content of the doxai is emphasized too, for here we see an ambiguity and intermingling that cannot permit us to infer absolute bright/positive/true (Alēthēs) or dark/negative/false (pseudēs) images but rather a mixture (Detienne, 1996: 134). The goddess informs her hearers of such a quality in order that they feel it in her narration and be aware of it. In other words, it means that through apate of the goddess, we are witnessing a mysterious transfer of meaning from thought to expression in the play of signification that leads to probable, apparent, and likely speaking in comparing with her certain, genuine, definite speaking, and thinking (F 8.50).

\section{Parmenides anonymity and time framework}

In reading the poem, we see there is no explicit mentioning to Parmenides; he is voiceless, silent, and does not speak for himself. It seems that being anonymous in name and speaking has some relation with Parmenides' conception of the philosophy manifest in the form of his poem. In other words, for understanding the rationale of his anonymity, it is necessary to make connections between his conception of philosophy and performance of such a conception in the oral and written forms, while remembering the specific and common characteristics of the didactic epic poem, as it is considered by Osborne (1998: 24, 26, 31).

Initially, I think through his elaborate anonymity (I have taken the idea from West, 2000: 99), Parmenides wants to introduce "knowledge" as a kind of "listening" to oral presentation (in comparison with "speaking"), in which the listener reflects on what hears by his or her own thoughts and then send it to memory. As a result, it is necessary that Parmenides shows and actualizes his idea about knowledge as listening. We can see that he does it through creating a friendly and personal relation between the goddess and any hearer like himself. It means that as a didactic performance, Parmenides himself experienced it in the past, or experiences it at any time and that the performance will be repeated by any reader of his poem in the future. In other words, in the mutual correlation of listening and anonymity, what Parmenides says and replies is not important. Instead, it is crucial to provide and facilitate such a cordial individual connection for any addressee, so that each individual undergoes alive, internal, practical, and personal journey. The experience is perceived as "oral", because during her speech the goddess speaks repeatedly and exclusively of an alive "hearing" in relation to her "voice", because "knowledge" resides in "listening" and not "seeing". We may understand this in relation with Parmenides poetical writing in space, because it is transmitted and narrated by the other intellectual authorities not himself and should be read aloud in order to be heard (West, 1995: 47- 49).

We can say that Parmenides inheritance of oral performance from Homer enhances this issue and negates any distance and gap between what the goddess says/does and what we try to think/say/act because she is speaking directly to her audience without any mediation by Parmenides; in such a context, the important issue is presenting and communicating the truth about the intended subject-matter. And it is exactly the purpose of Parmenides that provide a favorable and suitable context so that truth easily transported to the interested individual in the future rather than to account for his own idiosyncratic ideas, reactions, questions, and answersalthough I do not negate this fact that goddess speaking is double (Tarrant, 2000: 79-80 - though this is said in relation to ancient conceptions of mouthpieces in Plato's dialogues).

Although, we and Parmenides are equally the target group of the "goddess" speaking, here in this paper, we are searching for Parmenides' reflections. As a result, we should look for Parmenides' own hints that can be explored and thought about. It seems that the places in which we see two explicit, distinctive, and discontinuous interventions (in fragment 8: 39, 51) of "human" ideas into the goddess' speech and performance are exactly those places that we should seriously attempt to extract Parmenides' thought. From grammatical point of view, the qualities of these 
interventions are very complicated, for both of them are presented in the simple past tense.

The Aletheia level denotes to a truth that should be a norm, and as long as other people do not hear it, they cannot shape their true ideas and decisions. Thus, after the communication such an idea to the other people by Parmenides, the use of future tense is more acceptable. But how using simple past tense can be justified because it means that they have heard it in the past and goddess is accounting a passed issue.

In comparison with Aletheia, Doxa level denotes to the common ideas of the people either before or after revelation of goddess, so using past tense is justifiable. But in both cases, people are reacting to the thought of Parmenides after he has communicated the idea. That is, unless we think that the time frame is not pertinent to the discourse of the goddess, what she says to Parmenides individually is revealed for the other people too. In other words, if this journey is something personal, how are the other people simultaneously informed of its content and reacting in the form of naming? Unless we say that the past and future time frames are intermixed or unrelated in the goddess speech or, that she mentions the future because her path has not been communicated to the other human yet, we cannot speak of their responses and reactions unless we delete time and conclude that all things are present for the goddess.

\section{Who speaks for Parmenides?}

Although such a question is normally considered in relation with Plato's dialogues but we can trace Plato imitation back to Parmenides poem (Miller, 1999: 259-264). In the case of Plato, both the internal differences between what Plato has Socrates say to different interlocutors and the differences between Socrates's comportment and the comportments of other protagonists (Parmenides, the Eleatic Visitor, Timaeus, Critias, and the Athenian Stranger) make evident that we cannot assume that any one of these protagonists, Socrates included, may be identified with Plato; this is of course reinforced by the fact that at least twice he has his interlocutors mention "Plato"; once explaining why he is absent from the group (Phaedo) and once referring to him as present and ready to pay a fine in Socrates's behalf (Apology). What is more, within single dialogues, Plato has Socrates speak differently in different parts of the same dialogue, that is, in different phases of his educational encounter with his interlocutor. All of this means that as readers interpreting the dialogues, we are faced with the task of reading between the lines, that is, distinguishing the surface or explicit meaning of the protagonist's words, recognizing the dramatic context to which his speech belongs and understanding the way it is attuned to that context, and identifying the inexplicit commitments and insights that guide Plato in designing both this context and the protagonist's speech.

I think that the case of the poem of Parmenides is both the same in some ways and different in others. The narrator is, I take it, the kouros whom the goddess addresses near the end of Fragment 1. But he puts the goddess's speech to him in direct discourse, and this seems designed to give us the strong impression that we hear her words directly, with no framing or distortion by the kouros, from the end of the first fragment through the rest of the poem. Nothing I can find in the text suggests that the kouros alters her words either intentionally or unintentionally in his report of them. This means that we need not read between the lines of her speech in order to try to identify a meaning deeper than what the kouros reports that she says to him-with one important exception. When at the end of the eighth fragment, she declares that she will "end her trustworthy speech and thought concerning truth" and teach the kouros "the opinions of mortals", she warns the kouros that, since from "now on" she will be presenting not the truth but only the best of what we mortals think (why the best? because to learn it will prevent him from being "outstripped" by any other "thought of mortals" [8.60] - so this is as close to the goddess's standpoint as mortals can come without her intervention), he must "pay heed to the deceptive order of [her] words" (8.50-52); accordingly, from 8.50 on, hence in all of the fragments from nine 
to nineteen, we do have the task of distinguishing what the goddess explicitly says and the truth that she knows but withholds.

If these thoughts are correct, then there is nothing in the text of the poem that suggests that we should distinguish what the goddess is reported as saying in the so-called "truth" section of the poem (fragment 1.24 through 8.49) from what Parmenides regards as the truth. In this sense, it is safe to say that, "the goddess speaks for Parmenides" in B1.24-8.49. In reading fragments 8.52-19, however, we should qualify this. Here, though the goddess still speaks for Parmenides, she-and he-speak not what they regard as the ultimate truth but only the best of mortals' opinions (personal correspondence with Professor Mitchell Miller. See also Cherubin, 2001: 279 n. 5).

\section{Human naming}

During her speech, goddess pauses in two places in order to mention to the approach

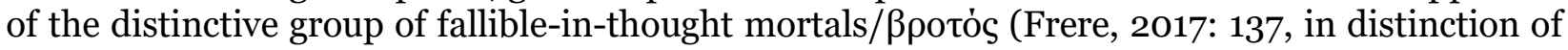
two other family words $\varphi \omega ́ \varsigma$ and óv $\theta \rho \omega \pi о \varsigma)$ to naming on the both levels of Aletheia and Doxa. Therefore, response of the intellectually fallible mortals to the subject-matter of being on the levels of necessity and contingency is narrated by the action of naming and its result, names. The presence of being and its properties prompts naming on the side of those groups of human beings who are neither wise men/ $\varphi \omega ́ \varsigma$ nor mortal living beings/ő $v \rho \omega \pi$ ภ but some intellectually fallible

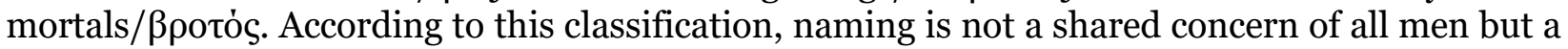

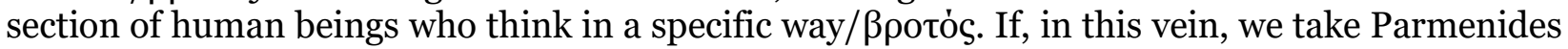

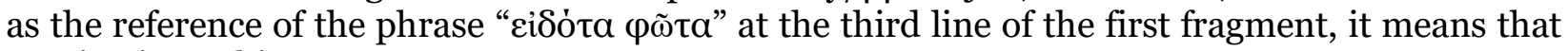
naming is not his concern too!

For considering naming by the intellectually fallible mortals/ $\beta \rho$ otós, we will consider the narration of goddess about a pre-language substantive subject on the one hand, and then the lingual reaction of the aforementioned mortals when they are on the way of Aletheia and Doxa on the other hand. As it is, goddess' speech and human receptions denotes the existence of a prelinguistic Ursprung, which functions as a foundation for any thinking; speaking and naming that comes after and over it. Interestingly, such a conception of being leads and calls on physis. Up to this section of our paper, physis has not been mentioned, but here is the exact place that it should be come on the scene: being that is the end result of its becoming. In this vein, while the root of the word denotes to grow the word as a whole denotes what is. Because on the one hand and at the core, goddess and Parmenides are speaking of being as an immaterial that emerges of itself and has abiding sway. On the other hand, if we take physis in its broad initial immaterial meaning of what comes-out-in-itself from-itself (Heidegger, 2000: xiii, 15,16, 64) and thereby all other beings come into being after it, then the emergence of all other things is dependent on this uniqueconclusive physis. Thus, we see that there is an analogy between being and physis (that is not concealed in Heidegger, see Vick, 1971: 145, 146) and it is according to such a conception that we consider Parmenides as the first poet-philosopher of physis/physiologos who connected a metaphysics with an epistemology.

When particular human beings hear or read about to be that takes multiple phonetical appearances and linguistic modalities, such as $\pi \lambda \dot{\eta} \theta \omega$, $\tau \varepsilon \lambda \dot{\varepsilon} \theta \omega$, and the like through the mouth of goddess, we expect that they say something to themselves or others as their receptions and conceptions of these different forms. Although silence has the virtue of making the continuation of the goddess narration possible, this is not the norm. Thereby, some thoughtful mortals break their silence by saying something after learning of a being that comes into being and is revealed through speaking as a specific being. Therefore, it is through true speaking (as a being) that thinking about being becomes manifest. Being then in turn becomes the subject of true speaking and thinking. But it is like our usual way of speaking and thinking and it is not limited to the 
goddess and Parmenides.

At the same time, in reading the poem, we see that within Aletheia level in Fr. 8. Line 17 for the first time in the whole of poem, goddess, in a specific road of inquiry and not generally and unconditionally (Cherubin, 2001: 294) speaks of being unthought/àvóntov: being

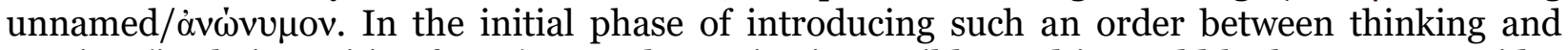
naming (in their positive forms), any alternative is possible, and it would be better to consider them in paratactic form (for this as a form of composition in the whole of the poem, see Mourelatos, 2008: 3-4). The relation between two words is very important for our paper; it is also an enigma that should be worked on in its own terms in human beings and Parmenides. In the goddess' first mention of naming, she brings it both in a paratactic relation with thinking in a

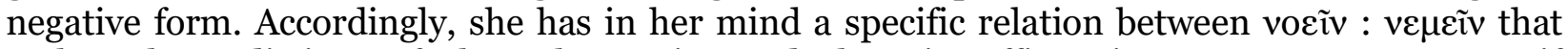
makes them distinct of the other pairs and then in affirmative terms we can say, if thinking/conceiving/knowing: naming.

Thereby we should consider the paratactic form of thinking: naming" in order to figure out perception of goddess and specific groups of intellectually fallible mortals who make names in the both spheres of Aletheia and Doxa. From our perspective, different modalities of "to be" in the Greek syntax can be the beginning block for anyone who wants to speaks of them. In hearing and reading them, the listeners and readers face problems they have never confronted, as a result, it is a new experience for them (otherwise there is no valuable novelty). It means that the speech of the goddess/Parmenides about the modalities of "to be" leads its listeners to think and then have conceptions about them. We, in turn, read and see both their thinking and speaking in the form of written words in a specific language. Thus, where there is nothing or when nothing is said by the goddess/Parmenides about modalities of "to be", it is unthought and unnamed. But when it is said in order to show conceptions of these linguistic forms, thoughtful though fallible mortals are mainly divided into two specific groups, although both of them recourse to onoma as a general word, far away from Plato and Aristotle conceptions, for giving phonetic manifestation (Heidegger, 2000: 61) to what is in their thoughts.

In addition, speaking of two levels necessitates choosing an appropriate method. As a result, we use the two-level model as it is introduced and used initially by Holger Thesleff in 1999 for Plato dialogues. This ontological view, which functions as a thought-experiment, is not pointedly dualistic and includes pairs of asymmetric hierarchical contrasts which are internally complementary and mutually associative. Neither level exists in isolation from the other: There are not two separate worlds, conflicting dynamic centers, or cosmic opposites. One level is good and leading and the other is less good and oriented to the former (Thesleff, 2000: 59, 60; Thesleff, 2002: 1). Therefore, modalities that are spoken by goddess work as the cause and lead some thoughtful human beings towards name-making as a revelation by means of sound (phone) in relation to and about being on the two levels of Aletheia and Doxa.

This interpretation is justifiable when we are working in the framework of an organic, ordered, sequential hypotaxis but in "thinking: naming", this is not the case. In this specific and crucial spot of the poem, we observe two parallel words that are juxtaposed with each other without any punctuation marks to show their relation. Accordingly, they should be translated and interpreted paratactically. This means that the syntactic and logical relations of these two words are open and cannot be put in a tight closed box. As a result, we can say that of "the two or more things (or ideas) that might be logically or otherwise connected with each other are each viewed separately, and the beholder or narrator is aware of only one at a time-parataxis in various forms" (Perry, 2016: 493; and Notopoulos, 1949: 10).

Before speculating about thinking in the oral performance context of the poem, we expect that specific types of saying be considered and emphasized as starting blocks before we reach thinking. For example, on the first line of the sixth fragment, we face with the word "saying" 
in the form of $\lambda \dot{\varepsilon} \gamma \varepsilon ı$. This opens the subject of goddess speech in relation to thinking. Besides, goddess articulates her different modalities/names of being. This signifies that she wants to articulate into names what he perceives as the physis of "to be". It also suggests that name and naming is not restricted only to human field (about modalities as names, see Goff, 1972: 77). In this regard, if we limit ourselves to the same sixth fragment, then by names of being, I mean غ̇òv

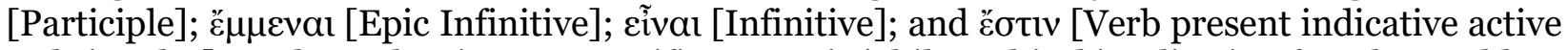
3rd singular]. Each one has its own specific syntactic/philosophical implication for what goddess perceives and thinks of the being physis. Therefore, in the context of orality, $\lambda \dot{\varepsilon} \gamma \varepsilon ı v$ lays out being open and in other words state it and, as a result, it has a relatively defined relation with perceiving/thinking but the relation of thinking with naming, on the other hand, is narrated in paratactic order.

Apart from $\lambda \dot{\varepsilon} \gamma \varepsilon ı v$, another word for saying that is used by goddess in relation to vocĩv is $\varphi \eta \mu \mathrm{i}$ (F. 8 Line 8). The verb $\varphi \eta \mu$ i alone covers 39 pages of the first part in Fournier (1946) in distinction of the other Greek words for saying. On the basis of exploring its different uses and forms, its core denotes not to any kind of saying but a kind of saying that comes from a definite idea or belief. Its speaker wants to declare and disclose something important and determinate (Buck, 1915: 126， 127; http://stephanus.tlg.uci.edu/lsj/\#context=lsj\&eid=113269: 1843). Therefore, $\varphi \eta \mu$ i is basically a statement and report in the form of saying, rooted in and analogous to the opinion of a speaker. As such, it stimulates thinking in its hearers and readers and so cannot be a trivial, unimportant, unthought, and usual saying.

Now, with regard to our clue in the 7oth verse of the eighth fragment, it is appropriate to consider the meaning of "voeĩ " more deeply and then turn to its paratactic and parechesis relation with " $v \varepsilon \mu \varepsilon \tilde{v} v$ " that is the concern of both divine and thoughtful human mortals.

It is granted that when goddess says (equivalent for both $\lambda \dot{\varepsilon} \gamma \varepsilon \imath / \varphi \eta \mu i$ ) different modalities of being, the mind of the young boy or any other thoughtful mortal becomes stimulated and blooms. It means that in the context of orality, thinking/conceiving/knowing does not have an independent and autonomous position, but derives from something external, that is, the speech of goddess about being and its modalities. Therefore, the initial feature of vónoıs as verbal noun is dependent on receiving and internalizing the modalities of "to be" that are spoken/said by goddess.

The modalities of being which the goddess reveals for the first time are intuitive, ambiguous, and unclear for human beings. They should thus be reasoned and explained in order to become clear, distinct, reasonable, and understandable (von Fritz, 1974: 52). Interestingly, he narrates the intermixture of these two elements in vocĩv with the dominance of reasoning. In the initial lines of the eighth fragment, which points to the rationale and standards of human naming, we see that on the favorable and recommended route of goddess describes thinking on the divine

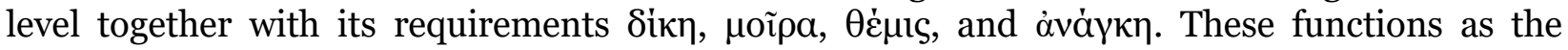
framework of thought and naming (f.8: $13-15 ; 29-32 ; 36-38$ ). In other words, it seems that she wants to make connection between thought with signs. The qualities of these signs (according to Nagy, 1983: 36-44 include: plurality, diversity, the ability to be decoded, recognizable, noticeable, non-forgettable, and interpretable). These qualities make them apt for the formation of thinking. As a result, the qualities work as "route signs" of Aletheia so that thinking reaches its object, being. Thinking is therefore both passive and active. It is passive when it receives the right signs, and it is active when it is more cognitive and works on signs. Moreover, without any exception, goddess and humans need "route signs" in order to continue their walk toward being. We should note, however, that all these distinctive signs are not suspended in the air but placed within a specific frame with four specific divine elements. And it is ideal that they have meaningful and organic relations with the route signs (Cherubin, 2001: 297, 298 n. 24). But it is not always so. According to the goddess, there can be unwelcoming relations among attributes/predications (Santoro, 2011: 
$247,248)$ and between the rout signs and the elements that according to her give an elenchic

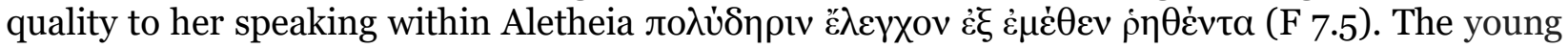
boy and any listener or reader should be aware of these relationships.

According to the core (Fr. 8) of the Aletheia level, the thoughtful mortal walkers should internalize the signs of being which are given on the way and spoken out through the catalogic/categorical speech of the goddess when she informs receivers of the attributes and predicates of all-inconclusive being: That is both the beginning/subject and ending/object of speaking-thinking-speaking.

Now with reference to the format "thinking: Naming" in their positive terms (Fr. 8, 17), it seems natural that when the receivers of being want to communicate their conception of being to themselves or others, it is necessary to speak and use language give phonetic/verbal clothing to their mind's conception of being (there is a similarity with Gorgias original conception). Here the main issue is solely the will of human beings to give phonetic materialization to the content of their mind (correct or wrong). Therefore, the usual antitheses that can come to our mind, such as onoma-ousia, onoma-ergon, onoma-rhema, and the like are irrelevant (Woodbury, 1958: 145; compare with Nussbaum, 1979; and Traglia, 1955). Before this materialization, allinconclusive being with its specific elements (Fr. 8, 3-38: unborn, impressible, indivisible, cohesive, immobile, unchanging, not incomplete) has only cognitive existence in mortal fallible minds. It will, however, take another kind of existence, realized by its phonetic formation from mortals' mouths (See the later reflection of this notion in: Plato, Sophist 261e). Such aphonetic realization has a broad sense and cannot be restricted to phonology and the subsequent developments and restrictions of this word. What the goddess says in elenchic format about being and its different modalities, mortals receive, consider, and then put in phonetic clothing. We should know that the goddess' elenchic way of speaking makes name-making a very difficult and complex venture. It means that thoughtful mortal beings try to present such phonetic manifestation through making-names. We use "name" here both as a comprehensive general word (Vlastos, 2008: 373, 374) and in its generic sense as signifying and naming something/the named (Ademollo, 2015: 34) before its differentiation and distinction of the other related words, which happens on two levels.

It should be noted that the recourse of human being to name can be considered a basic phase in the development of the Greek thought (Jaynes, 2000: 135). Besides, against the initial and older meaning of name and naming, in Parmenides, we see the transition of name as nomen proprium (proper name) to name as nomen appellativum (word); and as a result, we have the reflection of this status in the denominative verb ỏvoux́łelv too. Interestingly, such a happening denotes to the conception of Parmenides of sentence as a compound and not monolithic whole consisting of some specific elements, one of which is name with a specific identity (Gianvittorio, 2013: 14, 26). This identity is now a new factor in understanding human conception of being that will be discussed in what follows. For Parmenides, name has extension and application that is embedded and presupposed in all of the four pertinent fragments (Fr. 8, 38; Fr. 8, 53, Fr. 9, 1; Fr. $19,3)$. In addition, when we become more specific about naming, we find that Parmenides mentions and considers another element that clarifies his conception of naming (this issue is on

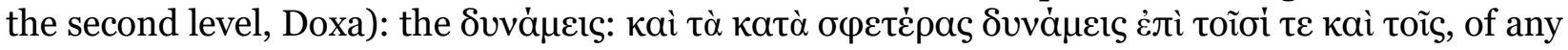

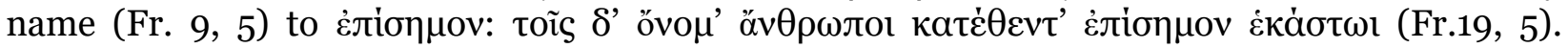
Accordingly, when we put these observations together, we can say that for Parmenides, a name is a phonetic/verbal construct with a specific Súvauı in relation to different named things. In light of this definition, we will now consider this specific element of name.

With regard to the use of the term "dynamis of names" (whether in the same form or by implication and indirectly with different meanings in ancient Greek thoughts on language (in Lysias; Herodotus; Plato and Aristotle, see Ademollo, 2011: 176-177), what can be Parmenides particular conception of dynamis in relation to name? An initial hypothesis might connect the 
dynamis of names with Parmenides' conception of being (Owens, 1975: 22; Woodbury, 1958: 154). Therefore, by onoma in its translation as "name" and not "noun" or "word", we want to say that name has the capacity to take being as its referent that has also a dynamic meaning (Woodbury 1958: 149, 151). This is a property unique to names and is absent in the comparable words with name.

Therefore, any name has a distinctive capacity/value that makes it name. In the context of classical thoughts, this means that a name conveys particular information about its

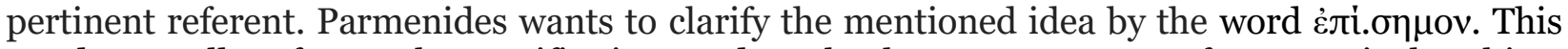
word generally refers to the specific signs and marks that come upon or after a particular object and give to it authority, formality, credit and value, otherwise they give opposite qualities.

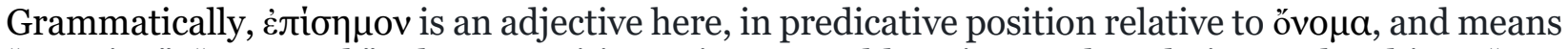
"as a sign", "as a mark". The preposition epi-presumably points to the relation to the object: "as a sign"/mark for (Epi + dative is used in this way with such verbs as onomazein or kalein). Therefore:

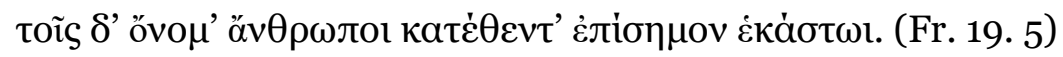

And on them men laid down a distinguishing name for each.

We should consider this image of name and naming within the two level-model of Thesleff (1999) as a heuristic guide, in distinction to a sharply dualistic model. There we are faced with the asymmetric contrast of Aletheia / Doxain a hierarchical order in which one is primary in all senses, but the latter is also necessary and prerequisite for the world as we have it. If the upper primary level is true and good, the lower secondary level is not necessarily bad or failed, but rather less good and oriented to the former.

Now we will consider naming and names on the first level/road that is the route of allinclusive or necessity being:

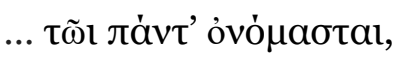

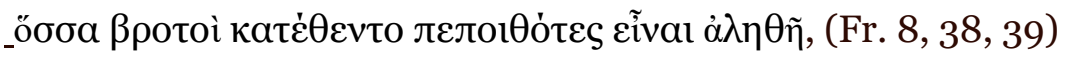

... Of this [being] all those [names] have been named,

As the mortals laid down, trusting them to be true: (Fr. 8, 38-41-Considering the Greek verb onomastai as a double nominative: Burnyeat, 1982: 19 n. 22)

According to these lines, after the revelatory and elenchic narration of goddess about being through its different modalities in the divine context, some thoughtful mortals hear such an account about being and attempt the difficult task of making names for this whole, which contains specific elements (compare: Diels, 1910: 7) and functions as the foundation or substance for any other being in the world. More concretely, they attempt this by making different names (Owens, 1975: 22, 23; Vlastos, 2008: 367 as the title of his paper denotes) in the form of four emphasized

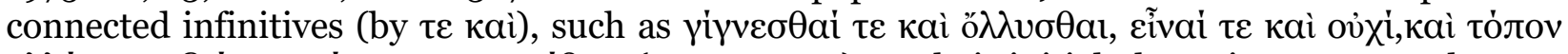

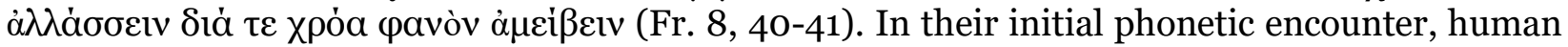
beings want to "refer" to and give some information about one all-inclusive unit that is "already" there (iлá $\rho \chi \varepsilon ı v)$. By moving on the road of Aletheia, that is embedded in elenchic speech they designate it. More importantly, the vocables that human lays down in the form of names should have the power to distinguish the relevant specific "given" unit (í⿱㇒́ $\rho \chi \varepsilon \imath v$ ) from other comparable similar or opposite entities, otherwise they have not fulfilled their function and value as names. In this case, they would not be suitable names at all, since a name should name something-in Greek, "name" as a noun and "to name" as transitive verb has close etymological relation with each other. This means that thoughtful mortals are "on" the proper road of Aletheia, even though it is possible to make mistakes (fallibility) when devising different names to express their understandings of goddess' account. They may make wrong though meaningful names (Vlastos, 2008: 372) with all- 
inclusive being as referent. In other words, it seems that the names that are made by some thoughtful fallible mortals cannot mark off all-inclusive being as is narrated by the goddess. She speaks of a whole with specific constituents or signs and the names only refer to a whole.

According to this interpretation, through the account of goddess/Parmenides, we are informed of the efforts of thoughtful though fallible mortals who are on the route of Aletheia. In order to signify the Ursache that goddess introduces, a group of thoughtful mortals laid

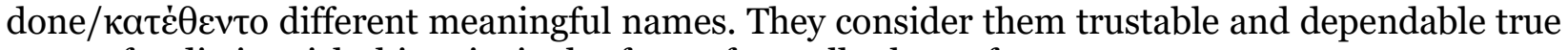
names for distinguish this principal referent from all other referents.

Some points need mentioning. With regard to this early introduction of the verb $\kappa \alpha \tau \dot{\varepsilon} \theta \varepsilon v \tau o$ before shaping of the afterwards antitheses, it would be better to translate this verb "to lay down" in order to avoid misunderstanding and also to convey its compound form in Greek (Diels, 1910: 8). With regard to the revelation of the being from the goddess and the presence of thoughtful mortals on the true route, without reducing true to orthotēs / right (Heidegger, 1993: 447), they venture to make human names. Therefore, they are not on the wrong way and making wrong name, otherwise they were completely out of route. More precisely, when we consider the human made names, it becomes clear that the power of name has not succeeded in distinguishing

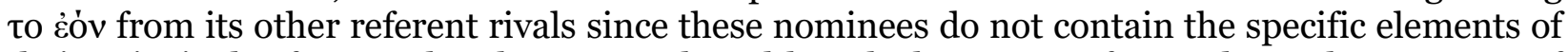
their principal referent. Thereby we say that although the names of mortals on the true way of necessity signify a whole as referent, the components or Merkmalsmatrix (Kraus, 1987: 90) of these names has no similarity with the signs of the goddess' referent. If this is the case, we can make a distinction between Bedeutung/reference and Sinn/sense and say that the four mortalmade names are true in their referent but not in the components that make its meaning (Frege, 1997: 152, 181-193).

According to our selected model, we consider the second level/route as doxa/appearance that is oriented to the primary path and includes different multiple conflictual possibilities/dia.kosmon eoikota (Fr. 8, 60. in Mourelatos, 1974: 318). And among these para.doxai, we are informed of one outstanding example of a dualism (Vlastos, 2008: 375) in relation to name-making. In other words, mortals on the Aletheia route ventured to make four names in order to signify their principal referent and give some information about it. But Aletheia is not the only route, for according to the Parmenides' poem, there is also the route of contingency. On this road too mortals make names:

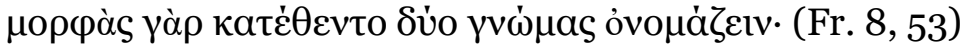

For they made up their minds to name two forms,

The sense of the verse is awkward and enigmatic, but ultimately it shows how thinking happens as a human action and how any thinker should manipulate names in order to set down a thought-Gorgias treatise is the best example of this idea (Mourelatos, 1974: 228; Woodbury, 1986: 2-4). In comparison with the Aletheia route, it might mean that human mind/gnomon governs and gains a basic secular role and function in relation to name-making (contra Woodbury, 1986: 3) without the overall divine elements and framework that functions on the first divine route. But a goddess who belongs to the level of necessity wants to reveal and speak of the different possibilities in the forms of doxai that can exist on the human level of contingency (Cherubin, 2005: 11). Because of this differentiation, the goddess informs that her speech is

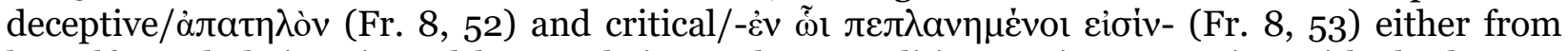
herself or Aletheia-oriented human beings. These qualities are in connection with the human naming and, as a result, we should consider human naming on the level of doxa that is narrated by goddess within it. In comparison with the previous reference of the goddess to the quality of her speech on the divine necessity level (7.5), on the human level of contingency she mentions to the nature of human opinions and one of the prominent ones which she critically informs us of the quality of human opinions that is reflected in her narration. Thus, on the human level of 
contingency, she resorts to one of the famous doxai/appearances of fallible mortals (Fr. 8, 51). As a result, the goddess as a divine being wants to re-narrate a specific human endoxa that like any other endoxa is on the border between right and wrong and has the capacity of deceivingalthough this does not mean that it is completely false (Cherubin, 2005: $13 \mathrm{n}$. 27), as immediately she mentions. Thus:

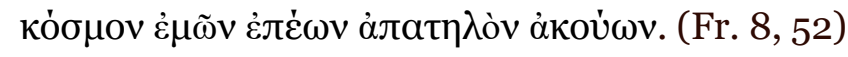

hearing the deceitful order of my speaking.

The goddess says that on the second route or level, we should expect to hear human endoxa from her mouth. The evaluative aspect of the goddess narration is revealed in the negative form of the word $\chi \rho \varepsilon \omega \dot{v}$ (which in its positive meaning denotes a necessity that comes from within and which can be the result of interests, inclinations, ideas, and appropriations) in distinction of $\delta \varepsilon \tilde{\imath}$ (which comes mostly of the external environmental and situational constraints that are outside of being) (pace Benardete, 1965: 285, 288). In other words, doxa or endoxa exists in an interworld. As a result, it is not completely right or wrong and should be examined so that these two aspects may be distinguished and differentiated.

On the level of doxa/appearance, thoughtful mortals proceed in their minds to name

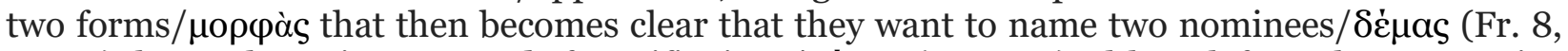
55 ; 59) that each one is composed of specific signs/oj $\mu \alpha \tau($ Fr. 8, 55), although from the perspective of goddess and Aletheia route they are one, that is: light. Thus, on the doxa route, it is possible that human beings put their mind together and make two distinctive names as external forms in order to signify their two distinctive internal referents/constructions (like the relation of façade with a building). According to this order we read:

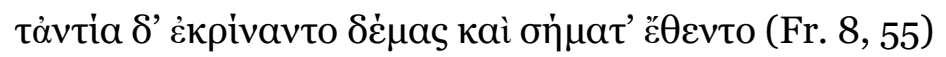

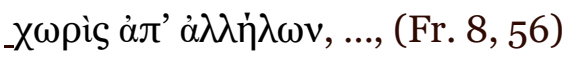

they distinguished contraries in body and set signs

apart from each other, ...

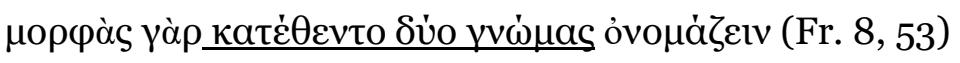

For they made up their minds to name two forms,

In comparison with the first divine Aletheia level, on the second human Doxa level, we are informed of two sets of which are "made" by thoughtful mortals. These forms are not given by the goddess bur are human made. Each one is imputed with specific distinctive signs, so mortals want to signify them through making two distinctive names. It seems that human beings have found something in names that can be applied to distinctive things and objects, such as night and light with the expectation that these can signify one referent from its opposite. But from the perspective of goddess and humans who are Aletheia-oriented, there is no successful differentiation on doxa level between being/light and non-being/night. But mortals think that they have succeeded in making a distinction between two referents and consequently, in making a unique name for each of them. As we mentioned before, it is exactly on this level that we are informed of the power and value of any name for the first time (Fr. 9, 4-5), that a name makes its referent distinct by designating unique signs for it.

But there is a problem on the doxa or contingency route that affects mortals namemaking. The goddess has a specific kind of discourse that is different from mortals' doxa. However, she tries not mention to her own true ideas or mention to them as thin as possible (Fr. 8, 54). Thus, she wants to re-introduce and re-represent mortals endoxa on a level that is, in comparison to the first road of necessity, the route of contingency. According to her narration, one of these mortal contingencies is the contrasting forms of light and night. According to goddess perspective, if we 
consider light as a reflection of being and night as a reflection of non-being the first one is thinkable and right name (meaning of $\chi \rho \varepsilon \omega \nu$ in the context of language) but the second one is unthinkable and wrong name. From the goddess' view, thoughtful mortals have gone astray by making two names, instead of one. Therefore, the thoughtful mortals' name for light (not night) as the secondary referent on the second contingency route that reflects the being as the primary referent on the necessity route is a right (not true) name.

\section{Acknowledgements}

This research did not receive any specific grant from funding agencies in the public commercial, or not-for-profit sectors.

The author declares no competing interests.

\section{References}

Ademollo, F. (2011). The Cratylus of Plato: A commentary. Cambridge: Cambridge University Press.

Ademollo, F. (2015). Names, verbs, and sentences in ancient Greek philosophy. In M. A. Cameron \& R. Stainton (Eds.), Linguistic content: New essays on the history of philosophy of language, Oxford: Oxford University Press.

Atherton, C. (1998). Form and content in didactic poetry. Bari: Levante.

Austin, S. (2007). Parmenides and the history of dialectic: Three essays. Las Vegas: Parmenides Publishing.

Barthes, R. (1993). Mythologies. London: Vintage.

Beaney, M. (1997). Frege reader. Cambridge, MA: Blackwell Publishing.

Benardete, S. (1965). XPH and $\Delta \mathrm{EI}$ in Plato and others. Glotta, 43(3/4), 285-298.

Bredlow, L. A. (2011). Parmenides and the grammar of being. Classical Philology, 106(4), 283-298.

Buck, C. D. (1915). Words of speaking and saying in the Indo-European languages: First \& Second Papers. The American Journal of Philology, 36(1), 1-18.

Burnyeat, A. M. F. (1982). Idealism and Greek philosophy: What Descartes saw and Berkeley missed. The Philosophical Review, 91(1), 3-40.

Cherubin, R. (2001). Legein, noein and to eon in Parmenides. Ancient Philosophy, 21, 277-303.

Cherubin, R. (2005). Light, night, and the opinions of mortals: Parmenides B8.51-61 and B9. Ancient Philosophy, Vol. 25, No. 1, 1-23.

Colavito, J. (2011). The orphic argonautica. Lulu.com. Retrieved from https://www.lulu.com/shop/jasoncolavito/the-orphic-argonautica/paperback/product-17grz4dy.html.

Cordero, N. (Ed.). (2012). Parmenides, venerable and awesome. Las Vegas: Parmenides Publishing.

Cosgrove, M. R. (1974). The KOYPO $\Sigma$ Motif in "Parmenides": B 1.24. Phronesis, Vol. 19, No. 1, 81-94.

Cosgrove, M. R. (2011). The unknown knowing man: Parmenides, B1.3. The Classical Quarterly New Series, Vol. 61, No. 1, 28-47.

Coxon, A. H. (2009). The fragments of Parmenides: A critical text with introduction, and translation, the ancient testimonia and a commentary. Assen: Van Gorcum.

Cunliffe, R. J. (1924). A lexicon of the Homeric dialect. Norman, Oklahoma: University of Oklahoma Press. Detienne, M. (1996). The masters of truth in Archaic Greece (J. Lloyd, Trans.). New York: Zone Books.

Diels, H. (1910). Die anfänge der philologie bei den Griechen. Leipzig: B.G. Teubner.

Dimock, G. E., \& Murray, A. T. (1995). Homer: The Odyssey. Cambridge, MA: Harvard University Press. 
Foley, H. P. (1994). The Homeric hymn to Demeter: Translation, commentary, and interpretive essays. Princeton: Princeton University Press.

Fournier, H. (1946). Les verbes “dire” en grec ancien. Paris: Klincksieck.

Frère, J. (2017). Mortals (ßротоí) according to Parmenides. In Lawrence J. Trudeau (Ed.), Classical and Medieval Literature Criticism, Vol. 185.

Gianvittorio, L. (2013). Sprechen und Verstehen bei Heraklit und Parmenides. Mnemosyne, 66, 1-29.

Goff, R. (1972). Saying and being with Heidegger and Parmenides. Man and World, 5(1), 62-78.

Gonzalez, F. J. (1995). The third way: New directions in Platonic studies. Lanham, MD: Rowman \& Littlefield.

Graeser, A. (1977). On language, thought, and reality in ancient Greek philosophy. Dialectica, 31(3/4), 359388.

Graham, D. W. (2010). The texts of early Greek philosophy (Part I). Cambridge: Cambridge University Press.

Heidegger, M. (1993). Basic writings, Second Edition, Revised and Expanded by David Farrell Krell. New York: Harper Collins Publishers.

Heidegger, M. (2000). Introduction to metaphysics. (G. Fried and R. F. H. Polt, Trans.). New Haven: Yale University Press.

Jaynes, J. (2000). The origin of consciousness in the breakdown of the bicameral mind. Houghton Mifflin.

Kahn, C. H. (1966). The Greek verb "to be" and the concept of being. Foundations of Language, 2(3), 245265.

Kraus, M. (1987). Name und Sache: Ein Problem im frühgriechischen Denken. Amsterdam: John Benjamins Publishing.

Lesher, J. H. (1984). Parmenides' critique of thinking: The Poluderis Elenchos of Fragment 7. Oxford Studies in Ancient Philosophy, 2, 1-30.

Liddell-Scott-Jones Greek-English Lexicon Online. Retrieved from https://stephanus.tlg.uci.edu/lsj/

Mason, R. (1988). Parmenides and language. Ancient Philosophy, 8, 149-166.

Messina, G. (1987). Index Parmenideus. Genova: Bozzi editore.

Miller, M. (1999). Platonic mimesis. In T. M. Falkner, N. Felson \& D. Konstan (Eds.), Contextualizing classics: Ideology, performance, dialogue: Essays in honor of John J. Peradotto. Lanham, MD: Rowman Littlefield.

Morgan, K. A. (2000). Myth and philosophy from the pre-Socratics to Plato. Cambridge: Cambridge University Press.

Most, G. W. (2006). Theogony: Works and days: Testimonia. Cambridge, MA: Harvard University Press.

Mourelatos, A. P. D. (1974). The pre-Socratics: A collection of critical essays. Princeton: Princeton University Press.

Mourelatos, A. P. D. (2008). The route of Parmenides. Las Vegas: Parmenides Publishing.

Murray, A. T., \& Wyatt, W. F. (1978). Homer: The Iliad. Cambridge, MA: Harvard University Press.

Nagy, G. (1983). Sema and noesis: Some illustrations. Arethusa, 16(1/2), 35-55.

Notopoulos, J. A. (1949). Parataxis in Homer: A new approach to Homeric literary criticism. Transactions and Proceedings of the American Philological Association, 8o, 1-23.

Nussbaum, M. C. (1979). Eleatic conventionalism and Philolaus on the conditions of thought. Harvard Studies in Classical Philology, 83, 63-108.

Osborne, C. (1998). Was verse the default form for Presocratic philosophy? in Catherine Atherton (ed.,), Form and Content in Didactic Poetry. Levante.

Owens, J. (1975). Naming in Parmenides. In C. J. de Vogel, J. Mansfeld \& L. M. de Rijk (Eds.), Kephalaion: Studies in Greek philosophy and its continuation offered to Professor C. J. de Vogel. Assen: Van Gorcum. 
Perry, B. E. (2016). The early Greek capacity for viewing things separately. Illinois Classical Studies, 41(2), 477-494.

Press, G. A. (2000). Who speaks for Plato? Studies in Platonic anonymity. Lanham, MD: Rowman \& Littlefield.

Rhodes, P. J. (2019). Herodotus: Histories, Book V. Liverpool: Liverpool University Press.

Santoro, F. (2011). Ta Semata: On a genealogy of the idea of ontological categories. In Néstor-Luis Cordero (Ed.), Parmenides, venerable and awesome (Plato, Theaetetus 183e). Las Vegas: Parmenides Publishing.

Semenzato, C. (2017). A l'écoute des Muses en Grèce archaïque. De Gruyter.

Taran, L. (1965). Parmenides: A text with translation, commentary, and critical essays. Princeton: Princeton University Press.

Tarrant, H. (2000). Where Plato speaks: Reflections on an Ancient debate. In Hayden W. Ausland et al. (Eds.), Who speaks for Plato? Studies in Platonic anonymity. Rowman \& Littlefield Publishers.

Thesleff, H. (1999). Studies in Plato's Two-Level Model. Helsinki: Societas Scientarum Fennica.

Thesleff, H. (2000). The philosopher conducting dialectic. In Hayden W. Ausland et al. (Eds.), Who speaks for Plato? Studies in Platonic anonymity. Rowman \& Littlefield Publishers.

Thesleff, H. (2002). An introduction to studies in Plato's Two-Level Model. Journal of the International Plato Society, 3, 20.

Traglia, A. (1955). Per la storia dei termini onoma e rhema e sul valore di onoma, logos ed epos in Eraclito e in Parmenide. In Contributi dell'Istituto di Storia della Filosofia dell'Università di Bari (pp. 147-161). Trani: Vecchi \& C. Editori.

Verdenius, W. J. (1949). Parmenides' conception of light. Mnemosyne, 2(2), 116-131.

Verity, A. (2007). Pindar the complete Odes. Oxford: Oxford University Press.

Vick, G. R. (1971). Heidegger's linguistic rehabilitation of Parmenides' "being”. American Philosophical Quarterly, 8(2), 139-150.

Vlastos, G. (2008). in A. P. D. Mourelatos, The route of Parmenides. Las Vegas: Parmenides Publishing.

von Fritz, K. (1974). Nous, Noein, and their derivatives in pre-Socratic philosophy (excluding Anaxagoras). In The pre-Socratics: A collection of critical essays. Princeton: Princeton University Press.

West, E. J. M. (2000). Why Plato does not speak? In Hayden W. Ausland et al. (Eds.), Who speaks for Plato? Studies in Platonic anonymity. Rowman \& Littlefield Publishers.

West, E. J. M. (1995). Plato's Audiences, or How Plato replies to the fifth-century intellectual mistrust of letters. In Francisco J. Gonzalez (Ed.), The third way: New directions in Platonic studies. Rowman \& Littlefield.

Woodbury, L. (1958). Parmenides on names. Harvard Studies in Classical Philology, 63, 145-160.

Woodbury, L. (1986). Parmenides on naming by mortal men: Fr. B8.53-56. Ancient Philosophy, 6, 1-13. 